\title{
Re-inventing virtual classrooms. How to implement virtual training that meets the needs of modern learners in a corporate environment?
}

\section{Klasy wirtualne zdefiniowane na nowo. Jak wdrażać szkolenia wirtualne w środowisku biznesowym, tak by spełniały oczekiwania współczesnych uczestników?}

\author{
Marcin Skrzek \\ Warsaw School of Economics, e-mail: mskrzek@tlen.pl; ORCID: 0000-0002-6189-8286
}

\begin{abstract}
Virtual classrooms continue to grow steadily and play an important role in a corporate learning environment. According to the 2018 Training Industry report 69\% of companies use virtual classrooms/webcasting/video broadcasting as one of the components of their digital learning ecosystem. Towards Maturity Health Check report published in Nov. 2018 projects a steady uptake of live online learning over the next 12 months by 55-85\%. There are different reasons why organizations decide to implement virtual training. Some examples include the lower cost, ability to reach learners across the globe or effective time management. Regardless of the reason, organizations should apply a structured approach towards the transition to lay the proper foundation and maximize the benefits. The aim of this paper is to present a holistic, end to end virtual classroom strategy definition process which addresses the needs of a modern learner and ensures successful implementation of virtual training. The study is based on a systematic review of the global literature, articles and research in the field of virtual classroom.
\end{abstract}

Keywords: virtual classroom, virtual training strategy, modern learner, instructional design, technology.

\begin{abstract}
Streszczenie
Klasy wirtualne odgrywają coraz większą rolę w grupie szkoleń korporacyjnych. Według opracowania 2018 Training Industry Report 69\% przedsiębiorstw korzysta już z tej formy szkolenia. Na podstawie danych przygotowanych przez Towards Maturity prognozuje się wzrost wykorzystania klas wirtualnych w ciągu najbliższych 12 miesięcy o 55-85\%. Różne są przyczyny, dla których przedsiębiorstwa decydują się na wdrożenie klas wirtualnych. Niektóre z nich to niższe koszty, możliwość dotarcia do większej liczby uczestników lub też bardziej efektywne zarządzanie czasem. Niezależnie od motywacji organizacje powinny stosować ustrukturyzowane podejście wdrożeniowe. Celem tego opracowania jest przedstawienie procesu definiowania kompleksowej strategii pozwalającej na implementację klas wirtualnych w organizacji biznesowej. Analiza została opracowana na podstawie systematycznego przeglądu literatury, artkułów oraz badań w obszarze klas wirtualnych.
\end{abstract}

Słowa kluczowe: klasa wirtualna, strategia szkoleń wirtualnych, współczesny uczestnik klas wirtualnych, projektowanie szkoleń, technologia. 


\section{Introduction}

There is a lot of literature and resources that discuss virtual classroom. They touch upon different aspects of this particular learning modality like instructional design, engaging delivery, facilitation techniques but there are not many references that can be seen as an ultimate guidebook for organizations to define, build and implement an end to end virtual classroom strategy. The aim of this paper is to present and discuss a holistic, step by step process that L\&D professionals should follow to implement virtual training in a way that allows organizations to meet the needs of a modern learner, transfer knowledge and affect business results in a positive manner. Based on a systematic review of the literature author proposes the following 6-step virtual classroom strategy framework:

- understand the modern learner,

- prepare the foundations,

- select technology,

- define instructional design principles,

- $\quad$ set trainers, producers and participants up for success,

- $\quad$ ensure smooth deployment.

Each stage of the process will be discussed in details in the following sections of this paper.

\section{Understand the modern learner}

Before discussing any training strategy it is of a paramount importance to understand the modern learner. Organizations need to make sure their learning offering is fit for purpose and meets the needs of a targeted audience. Those needs are dynamic and change over time.
In a nutshell, the modern learner is overwhelmed, constantly distracted and highly impatient. In 2014 Bersin by Deloitte conducted a study that revealed the following facts [Morris 2017]:

- $66 \%$ of knowledge workers complain that they do not have time to do their jobs,

- $41 \%$ of time workers spend on things that offer little personal satisfaction and do not help them get work done,

- today's employees get online 27 times a day,

- people unlock their smartphones up to 9 times every hour,

- workers get interrupted as frequently as every 5 minutes,

- most learners will not watch videos for longer than $4 \mathrm{mi}-$ nutes,

- online designers now have between 5 - 10 seconds to grab someone's attention before they click away.

Other findings in the study reveal that today's employees are untethered, appreciate highly collaborative environments and are keen on learning on their own. The key figures illustrating the above trends are as follows [Bersin by Deloitte (access 10.03.2019)]:

- $\quad 30 \%$ of full time employees do most of their work somewhere other than the employer's location,

- $80 \%$ of workforce learning happens via on - the - job interactions with peers, teammates, and managers,

- $38 \%$ of workers say they have opportunities for learning and growth at their workplace,

- $62 \%$ of IT professionals report having paid for training out of their own pockets.

The above statistics have got an important impact on the corporate learning environment. Despite the challenges

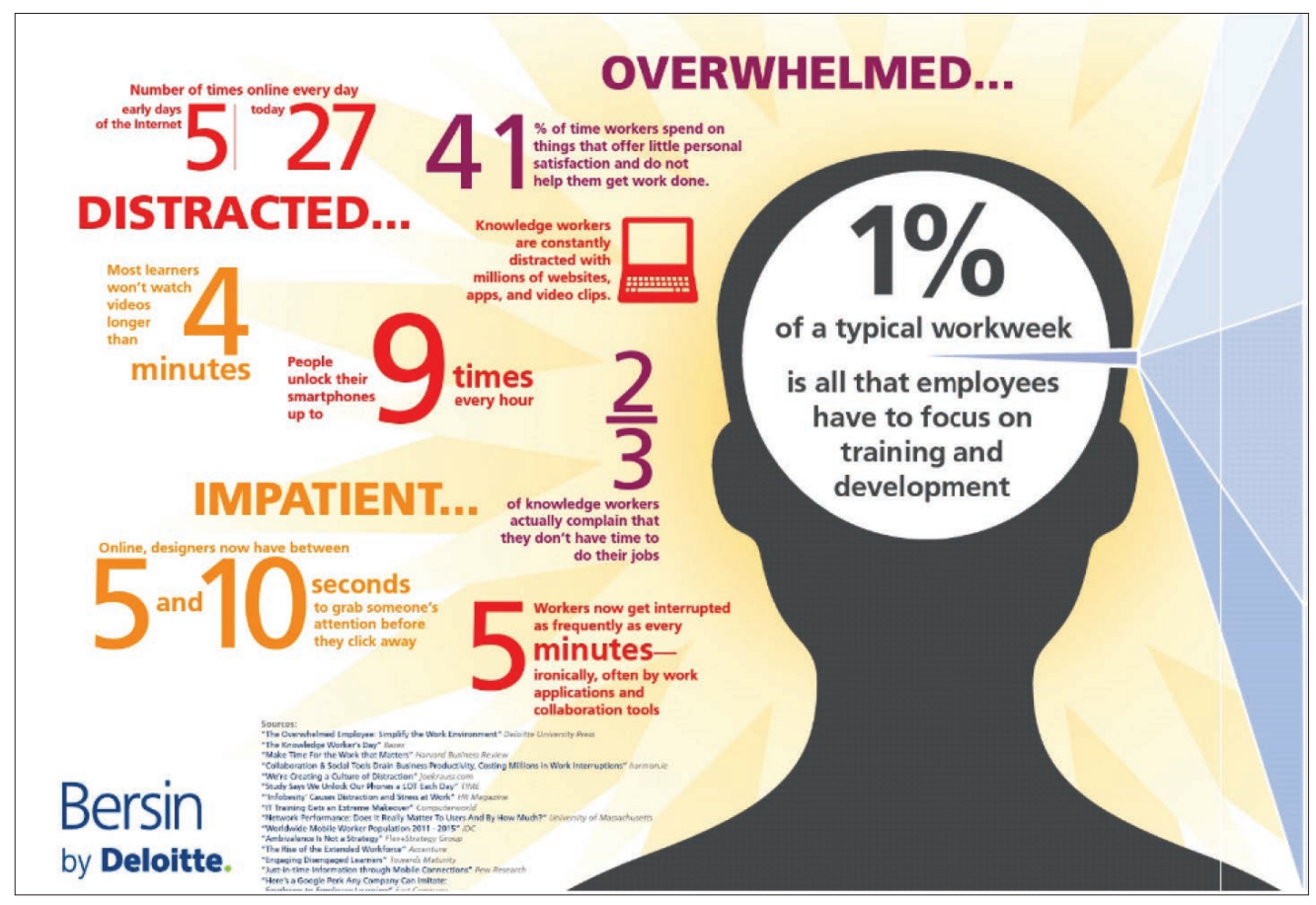

Figure 1. Key characteristics of the modern learner

Source: [Morris 2017]. 
outlined above organizations need to find a way to develop talents and provide learning opportunities. One way to tackle this is to leverage virtual training to its full extent by following a structured approach to define and implement relevant virtual training strategy.

\section{Prepare the foundations}

Regardless of the reason for implementing virtual training, organizations should get the foundations right. Those foundations will be the same independently of a scale of the transition and include the following elements:

- define the objectives,

- define virtual training,

- $\quad$ get buy in from business stakeholders.

Cindy Huggett, an independent consultant, virtual classroom instructional designer and facilitator, author who specializes in technology, leadership, and learning, describes this phase in the following manner. "The first task in any implementations is to plan for success. As well - known author Stephen Covey once wrote, 'Begin with the end in mind' (1989). The same thought is true for a virtual training implementation. Begin by thinking about the end goal" [Huggett 2013].

\subsection{Define the objectives}

First of all, organizations need to be crystal clear and internally aligned on why they have decided to implement virtual training. This will allow to draw a vision, define a specific purpose and identify expected positive outcomes of the virtual classroom. The pool of sample questions to ask includes the following:

- What are we trying to achieve?

- What added value can virtual training bring?

- How do we want our organization to be different as a result of the virtual training launch?

- How can our organization improve owing to virtual classrooms?

The questions above will not only allow to crystalize the intent and increase the likelihood of achieving it but, even more importantly, will help to determine whether virtual training is the right answer to business problems or challenges that are to be addressed.

\subsection{Define virtual training}

What is virtual training? How can we define virtual classroom? There are a lot of versions of truth and each organization can answer these questions differently. The key point is to define what virtual training means for a given organization and what the definition implies. What is in/out of scope?

The definition which is most commonly used and captures the key characteristics of the virtual classroom is as follows. "(...) a highly interactive, synchronous online, instructor-led training class, with defined learning objectives, that has geographically dispersed participants, each one individually connected using a web classroom platform" [Huggett 2017].
The above definition has been used in this paper to present and discuss the virtual training strategy implementation model.

Both, clear objectives as well as definition behind virtual training will help determine criteria for choosing virtual classroom as a format for a given learning project and will enable the selection of legacy face - to - face programs to be transitioned into virtual classrooms.

\subsection{Get buy in from the business stakeholders}

One of the most common mistakes made by L\&D professionals is trying to drive learning initiatives on their own, without the required level of internal alignment and support within an organization. This often leads to a failure or at least limits the expected benefits. Successful implementation plans are rarely created in isolation and virtual training is not any different in this case.

The typical roles involved in a virtual training roll out include:

- $\quad$ subject matter experts (SMEs),

- instructional designers,

- facilitators/virtual classroom trainers,

- virtual classroom producers,

- participants,

- coordinators/administrators,

- IT experts,

- budget owners,

- executive sponsor.

It is of paramount importance to get the right business stakeholders involved at a very early stage of the virtual training strategy definition and keep them in the loop of the key decisions made throughout the process. Their expertise, support and thought partnership ensure a smooth execution of the implementation plan at a later stage of the project.

\subsection{Business case example}

Cindy Huggett in her book "Virtual Training Tools and Templates. An Action Guide to Live Online Training" describes an interesting business case from Volvo Trucks that illustrates how the organization set the foundations for the virtual training roll out. "In 2013, Volvo Trucks started implementing virtual training. Jack Benedict and others in the learning department looked at the number of customers they needed to reach (450 locations across seven time zones) versus the training resources they had, and declared to explore online solutions. Jack and the team stared with the question, 'What would we tell them if we only had one hour? What are the key things that the learners could apply immediately?' They were looking for the most efficient way to deliver the most important concepts and landed on virtual training as the answer. They began to define virtual training - what it is and what it is not - and created a set of design principles to follow. They also began searching for a platform that had robust features yet would be easy for learners to use. And they began building the business case to gain buy in and acceptance throughout the organization. Jack's advice to others who are getting started with virtual training? He boils it down to three main things: 
1. Define a very small target for the initial virtual training implementation. Start with a simple topic and small audience that will have large impact on results. You can be forward thinking as a learning organization, but because change makes many people nervous, start small for success.

2. Define what virtual training is, and what it means to your organization. Document the definition and gain acceptance of it, so that it becomes your guidepost for design, delivery and implementation.

3. Define what tools you need for virtual training, then select a platform that has those tools. Also, make sure your organizational infrastructure can handle the platform so that people do not get frustrated by the technology" [Huggett 2017].

The above case is a practical, role model example of preparing foundations for successful virtual training implementation. It contains a set of ready - to - use tips and hints that can be leveraged by other organizations that consider virtual classrooms as a new learning modality.

\section{Select technology}

Once an organization is clear on virtual training vision, has defined its scope and identified relevant stakeholders, the next important step is to select a preferred virtual classroom platform. Currently, the industry offers so many options that selecting the right solution might pose a significant challenge. The 2019 State of Virtual Training research study highlights the following virtual classroom platforms as the most widely used within the corporate learning environment.

The above list is not exhaustive by any means. Other virtual training solutions used by organizations are Zoom, Blackboard Collaborate, Jigsaw, AirClass by Lenovo, Saba Virtual Classroom.

Selecting a preferred technology platform is the area where L\&D should work hand-in-hand with an IT department. There are lots of decision points at this stage of the process and support from the technical standpoint cannot be underestimated. The key consideration areas include:

- Hardware (PCs, mobile devices, webcams, headsets),

- Software (platform functionalities, integration with other systems, e.g. learning management system),

- Audio (telephone conferencing vs. voice over IP),

- Internet bandwidth.

Jennifer Hofmann, a recognized thought leader in the field of virtual classroom and synchronous learning, describes in her blog series the business case of a multinational software company that decided to implement virtual training with the objective to maximize the value of their existing learning content. “(...) As we've mentioned previously, one of the advantages of the virtual classroom is that it's fairly easy to implement and navigate. However, this doesn't mean technology barriers don't exist, especially within large companies. Some groups may have webcams, some may not. Some groups may not have enough bandwidth available to support live video streaming. Some individuals may work primarily on mobile devices. (...) It's important to understand what each group's learning environment looks like and what technologies they use (or don't use). Before committing to any delivery technologies, create a profile of target participants, including technology available, access to technical support, learning environment and training needs for that technology. (...) Our client already had existing technology in place, and it was standardized across the enterprise. Because of this, we needed to prepare their facilitators and learners to best use the existing technology, and to understand the virtual learning environment. Customized learner orientations, like our Learn How to Learn Online workshop, were implemented to teach the technology; and an infographic with troubleshooting tip was distributed. We also encouraged the client not to use all of the features in the platform right away. Doing so can overwhelm

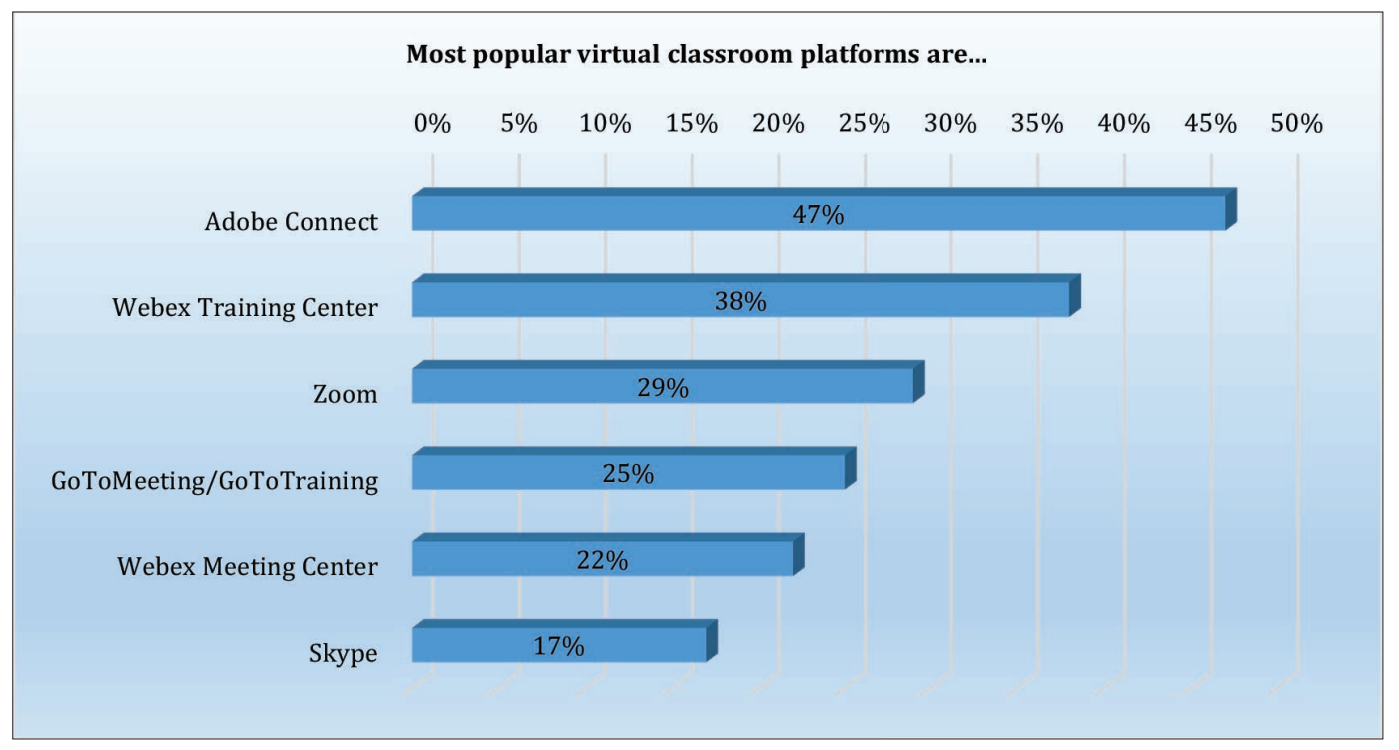

Figure 2. The most popular virtual classroom platforms

Source: own elaboration based on [Huggett 2019]. 
both the learners and facilitators. Instead, we suggested that they allow the learners to become familiar with the basics of the environment before moving on to using advanced collaboration tools like breakout rooms. It is tempting to jump in with both feet, but when all of the users are new, a deliberate approach to new technology works best. After several hands on interactive lessons, learners become more fluent in the virtual classroom approach. (...) Learners have embraced the new platform and their newly trained facilitators. Reviews have been excellent. By implementing a systematic approach to implementing the new technology, the new direction for delivering training was more readily embraced (...)"[Hofmann 2016].

\section{Define instructional design principles}

Good instructional design engages participants and ensures interactivity in a live online learning event. It is a critical success factor for effective virtual training. This is also the stage in the virtual classroom strategy definition process where organizations should address to the highest extent the needs of modern learners who are constantly overwhelmed, distracted, and impatient. It has also been said earlier in this paper that today's employees are untethered, appreciate highly collaborative environments and are keen on learning on their own.

According to the study conducted by Association for Talent Development (ATD) and Institute for Corporate Productivity (i4cp) in 2016 23\% of L\&D professionals claim that lack of learners' engagement impacts the effective use of virtual classrooms in their organizations [Association for Talent 2016]. The 2019 State of Virtual Training research study reveals that in $24 \%$ of organizations non-interactive program design is one of the top challenges of virtual training [Huggett 2019]. At the same time $91 \%$ out of 10000 workers surveyed across all demographics see collaboration as a key to a learning success [Towards Maturity 2018]. Moreover, 2018 State of Virtual Training research study mentions interactive design as one of 3 key success factors in virtual training [Huggett 2018].

The industry offers wealth of approaches, models, strategies and best practices that can be leveraged to design highly interactive and engaging virtual classrooms. Wendy Gates Corbett and Cindy Huggett propose a hybrid approach that combines the traditional ADDIE model with a few virtual classroom considerations. "The good news for designers is that the typical ADDIE process (analysis, design, development, implementation, evaluation) still works well as a model for designing synchronous online training. (...) When designing for the virtual classroom, pay extra attention to engaging participants. Because they are not face-to-face with the facilitator, special effort must be made to keep participants' interest throughout the session. Training needs to be relevant and presented in a way that sustains attention. Using a combination of familiar ADDIE principles and a few online classroom considerations, you can easily design effective and engaging synchronous programs" [Gates Corbett, Huggett 2009, p.1].
Katelind Hays, the Social Media Marketing Manager for InSync Training, proposes a 4-step instructional design model for engaging and interactive virtual live events [Hays 2019]:

- identify instructional goal and performance objectives,

- determine assessment needs/techniques,

- determine collaboration,

- determine authentic training technique.

Sam Hsu, Oge, Marques, M. Khalid Hamza, and Bassem Alhalabi in their research paper discuss a 10-step instructional design framework for virtual training [Hsu et al. 1999].

Regardless of an instructional design model an organization decides to follow, it is important to have one and apply it consistently across the entire transition from traditional classroom based training to highly interactive and engaging virtual live events. The same model will be applied in case of building brand new online learning that does not have its equivalent in a traditional face-to-face classroom.

The 2018 [Huggett 2018] and 2019 [Huggett 2019] State of Virtual Training research studies provide interesting insights on the most recent industry trends that virtual training instructional designers should take into account while building live online learning interventions:

- Most virtual classes have under 20 participants (81\% have 25 or less participants).

- Most virtual classes are 60 minutes in length.

- $66 \%$ of all virtual classes are under 90 minutes.

- Average amount of time spent developing a one hour interactive virtual class is 21 hours.

- $40 \%$ of virtual training classes are part of a blended curriculum.

- Virtual classes should engage participants with the tools or each other at least every 4 minutes.

The above trends and insights support the instructional design recommendations made by Cindy Huggett in her paper "Virtual training for modern learners" [Huggett (access 10.03.2019)]:

- reduce feeling of remoteness with social interaction,

- overcome distractions with an engaging experience,

- diminish "overwhelm" with purposeful design,

- create a simple user experience to eliminate overload,

- cater to learners' uniqueness with personalized solutions.

The above guidelines are ready-to-use techniques that make virtual classrooms respond effectively to the needs of modern learners.

A set of instructional design principles provides additional clarity and help accelerate design and then development of virtual learning programs. Virtual training strategy should specify whether this part of work (design/development of actual learning interventions) will be handled internally or outsourced. The third option for an organization is to use a hybrid model where, depending on a learning project, both internal and/or external resources can be used. 


\section{Prepare trainers, producers and participants}

The key roles in a typical virtual classroom environment include a facilitator, a producer and a learner. Everyone in one of these three roles needs to be upskilled and prepared to ensure an engaging and smooth virtual learning experience.

A facilitator's role in a virtual classroom is to lead a training session, teach content, run activities and facilitate discussion. Darlene Christopher, a Knowledge and Learning Officer at the World Bank Group in Washington DC, explains how to adjust traditional classroom facilitation skillset to take it to the next level and make it work in a virtual training environment. "Facilitating in the global virtual classroom presents the facilitator with a variety of challenges. If you already facilitate training for in-person global audiences, you will discover that the global virtual classroom will challenge you to overcome the absence of body language, because you cannot see your participants and they cannot see you. In addition, if you already facilitate in the virtual classroom and you are ready to add global participants, then you will need to focus on language awareness and cultural awareness. In either of these cases, the global virtual classroom facilitator builds on the facilitation techniques she already uses and adjusts to the unique needs of an international audience that is physically separated. Failing to adjust can mean running the risk of confusing and alienating global participants. In addition to general facilitation skills and subject matter expertise, the global virtual classroom facilitator has skills that span many areas, such as

- language and cultural awareness,

- multitasking skills,

- technology skills" [Christopher 2011].

A producer is a second person who acts as a session leader in a virtual classroom environment. His or her role is to be a technical expert, support all behind-the- scenes activities and provide technical assistance (whenever needed) to a facilitator and participants during a virtual classroom. According to the 2019 State of the Virtual Training research study 42\% of virtual trainers always (or almost always) use a producer or a co-facilitator. $27 \%$ never use one [Huggett 2019]. Producers need to be experts in technology and at the same time possess quite unique qualities that include problem solving skills, ability to remain calm under pressure and multitasking. Usually organizations hire an external partner who supplies producers on a class-by-class contract basis or upskill resources internally who then act as full/part-time producers for virtual training classes.

Participant preparation is often overlooked, yet it is an essential step to successful virtual training implementation. Knowing the profile of a modern learner (overwhelmed, constantly distracted, impatient) it is of paramount importance to set virtual classroom participants for success by helping them realize the true value of virtual training. Jenniffer Hofmann offers the following tips for preparing learners to develop and grow in a live online learning environment [InSync Training 2016]:
- Help change learner perceptions so that they can see the value of participating and not multitasking during the program.

- Start off with a single program or small number of programs to show the true value of virtual learning.

- Provide a basic skills workshop to build confidence.

- Use a producer to provide technical support.

- Do not use higher intensity tools (such as breakouts) until learners are comfortable with the platform.

Cindy Huggett in one of her book mentions three key ways to help participants prepare for virtual training [Huggett 2013, p. 124]:

- help them manage their learning environment,

- help them learn technology,

- help them change their mindset about virtual training.

Reviewing key roles in a typical virtual classroom and ensuring the right level of preparation, knowledge and expertise is an important step in the virtual training strategy definition process. Unprepared participants and unskilled facilitators are mentioned by L\&D professionals as one of the top challenges of virtual training. Therefore, the time invested in this part of the virtual classroom implementation cannot be underestimated.

\section{Ensure smooth deployment}

Organizations that start to consider virtual training roll out often underestimate the amount of time and effort required to set up logistics for successful online learning events. Most global organizations with an established virtual training strategy employ one or more coordinators/administrators who handle logistical details of virtual learning programs. The key activities performed by a person in the role include setting up an offering in all systems/platforms used to deploy a given training, managing registrations, program communication, sourcing a producer, logistical support for learners throughout a program, progress/completion tracking, reporting. It is of paramount importance for organizations to define an administrative role and secure resources to take care of logistical details at an early stage of virtual training implementation. The admin processes should be kept simple and standardized for all virtual classroom programs deployed across an organization. Also, apart from a regular set of logistical activities performed on a class-by-class basis it is important to secure resources which will cover ongoing maintenance activities related to virtual training. This includes vendor/contract management, regular reviews of licenses, platform support and maintenance, managing technology updates. These types of activities are more general in nature and are not tied to any specific training events.

\section{Conclusions}

Defining a robust, end-to-end virtual training strategy requires a structured approach that takes into account both business objectives of an organization as well as the needs of a modern learner. This paper draws a holistic, ready-to-use, universal model that can be applied by any organization regardless of its size or an industry. It is a high level framework and each 
step of the proposed process could be a subject of a separate paper. Also, getting a modern learner's perspective ('As is' vs. 'To be') on the specific aspects of the virtual training strategy, especially in the area of instructional design, deployment and participants' upskilling/preparation, would be an interesting add to the proposed model.

\section{References}

Association for Talent Development (ATD), 2016, Virtual classrooms now. Using Technology to Reach Today's Workforces, ATD Press, Alexandria.

Bersin by Deloitte, Leading in Learning. Building capabilities to deliver on your business strategy, https://www2.deloitte.com/content/ dam/Deloitte/global/Documents/HumanCapital/gx-cons-hc-learning-solutions-placemat.pdf (access 10.03.2019).

Bersin by Deloitte, 2014, Meet the Modern Learner, https://www.socialtalent.com/blog/learning/meet-modern-learner-infographic (access 10.03.2019).

Christopher D., 2011, Facilitating in the Global Virtual Classroom, ASTD Press, Alexandria.

Gates Corbett W., Huggett C., 2009, Designing for the Virtual Classroom, ASTD Press, Alexandria.

Hays K., 2019, Four Steps to Contextual Virtual Learning, https://blog. insynctraining.com/four-steps-to-contextual-virtual-learning (access 10.03.2019).

Hofmann J., 2016, Part 3: Managing Virtual Classroom Strategy Implementation Challenges, https://blog.insynctraining.com/part-3managing-virtual-classroom-strategy-implementation-challenges (access 10.03.2019).

Hsu S., Marques O., Hamza M. K., Alhalabi B., 1999, How to Design a Virtual Classroom: 10 Easy Steps to Follow, https://www.researchgate.net/publication/251433475_How_to_Design_a_Virtual_Classroom_10_Easy_Steps_to_Follow (access 10.03.2019).
Huggett C., Virtual Training for Modern Learners, https://www.cindyhuggett.com/archive/virtual-training-for-modern-learners/ (access 10.03.2019).

Huggett C., 2008, Simple, Effective Online Training, ASTD Press, Alexandria.

Huggett C., 2010, Virtual Training Basics. How to Design, Deliver, and Implement Live Online Learning, ASTD Press, Alexandria.

Huggett C., 2013, The Virtual Training Guidebook. How to Design, Deliver, and Implement Live Online Learning, ASTD Press, Alexandria.

Huggett C., 2017, Virtual Training Tools and Templates. An Action Guide to Live Online Learning, ATD Press, Alexandria.

Huggett C., 2018, The State of Virtual Training: 2018 Edition, https:// www.cindyhuggett.com/blog/sovt/ (access 10.03.2019).

Hugget C., 2019, The State of Virtual Training: 2019 Update, https:// www.cindyhuggett.com/blog/2019sovt/ (access 10.03.2019).

InSync Training, 2016, Infographic - 7 Actions to Manage \& Overcome the Challenges of Implementing a Virtual Classroom Strategy, https:// blog.insynctraining.com/modern-learning-resource-library/7actions-to-manage-overcome-the-challenges-of-implementing-avirtual-classroom-strategy (access 10.03.2019).

Morris A., 2017, Meet The Modern Learner (Infographic), https://www. socialtalent.com/blog/learning/meet-modern-learner-infographic (access 10.03.2019).

Towards Maturity, 2018a, Challenging business assumptions about how workers learn, https://towardsmaturity.org/2018/12/06/challenging-business-assumptions-about-how-workers-learn/ (access 10.03.2019)

Towards Maturity, 2018b, The Real Learning Technology Trends for 2019, https://towardsmaturity.org/2018/11/22/the-real-learning-technology-trends-for-2019/ (access 10.03.2019).

Training Magazine, 2018, 2018 Training Industry Report, https://trainingmag.com/trgmag-article/2018-training-industry-report/ (access 10.03.2019). 